\title{
FAITHLESS ISRAEL, FAITHFUL YAHWEH IN DEUTERONOMY ${ }^{1}$
}

\author{
Paul A. Barker
}

The purpose of this thesis is to investigate the perception of Deuteronomy regarding Israel's ability to keep the covenant requirements. Often Deuteronomy is regarded as an idealistic book, holding out the possibility of utopia in an Edenic land. Yet the hope of Deuteronomy is tempered by an acknowledgement of Israel's propensity to fail. This contributes to a pessimistic expectation for the future which lies in some tension with the book's optimism. It is the contention of this thesis that all optimism in Deuteronomy is grounded in the faithfulness of Yahweh to the Abrahamic promises and that, with regard to Israel, there is only a pessimism about the future. Nonetheless, these two strands are not in fundamental opposition to each other, as diachronic and redaction critics frequently imply to be the case. This thesis, which deals with the book synchronically, argues for the theological integrity of these points of view within Deuteronomy.

This thesis restricts itself to the three major accounts of Israel's failure in the book, along with their respective accounts of resolution. These are: (1) Deuteronomy 1-3, which include the spies incident and the resumption of progress to the land; (2) Deuteronomy 8-10, which include the golden calf episode and its resolution in the answered prayer; and (3) Deuteronomy 29-30, which include the expectation of Israel's failure and subsequent curses, as well as the promise of restoration. In each case, Israel's failure finds resolution in the faithfulness of Yahweh to the Abrahamic promises. This thesis argues that, in the interplay between Yahweh and Israel, there is a priority on

1P.A. Barker, Faithless Israel, Faithful Yahweh in Deuteronomy (Unpublished Ph.D. thesis, Cheltenham and Gloucester College of Higher Education, University of Bristol, 1995); supervisors: Professors G.J. Wenham and J. Barton. 
Yahweh's grace which guarantees a future for Israel despite her sin, but does not override human responsibility.

Deuteronomy 1-3, by contrast with parallel accounts in Exodus and especially Numbers, emphasises Israel's sin. In chapter 1, the people are isolated in their refusal to enter the land. The spies' report (1:25), which is at the heart of the chiastically arranged speeches of 1:6-39, is unequivocally positive. The juxtaposition of Israel's refusal (1:27-28) highlights its baseless sin. The use of first-person plurals and secondperson address identifies the current generation with its sinful predecessor. This technique of generational conflation throughout Deuteronomy suggests that past sin is paradigmatic for Israel. The language of 'unholy war' and 'antiexodus' in these chapters further casts Israel's sin in the worst possible light. Yet, despite such sin, there remains a future for Israel. The possibility of such a future derives from the promise of land, mentioned explicitly and programmatically in 1:6-8. This promise guides the progress of Israel in chapters 2 and 3, in its confrontations with the five Transjordanian nations. Chapters 1-3 concentrate, in fact, on Yahweh's faithfulness to his promises. The fulfilment of the Abrahamic promise of descendants is expressed in 1:9-18. Transjordan is described in terms which suggest a partial fulfilment of the promise of land, thereby encouraging Israel to trust in the complete fulfilment of that promise. So Israel's victories over Sihon and $\mathrm{Og}$ are attributed to Yahweh's faithfulness, not its own ability.

Deuteronomy 8-10 focuses on the golden calf incident. Where the spies incident was a failure with respect to land, this is failure regarding the law. As with the spies incident, this sin is portrayed in paradigmatic terms. The making of the golden calf is not an isolated sin but is symptomatic of Israel's sinful condition. As with the spies incident, the resolution of the failure into hope for Israel rests exclusively on Yahweh's faithfulness to the Abrahamic promises, as Moses' intercession indicates. No hope is placed in Israel and Yahweh's action in restoring the relationship does not depend on any contrition or change within Israel. Even chapter 8 is pessimistic regarding Israel. The rehearsal of the wilderness events focuses on Yahweh's gracious provisions in the context of times when 
Israel failed, e.g. the manna incident. Chapter 8 moves from optimism to pessimism, suggesting the orientation of the book. It expects Israel to fail.

The heart of this thesis is the discussion of Deuteronomy 29-30. Chapter 29 reveals an expectation that the curses are no longer an alternative but are expected to happen because Israel will fail. This derives from 29:3, a key verse, which expresses Israel's deficiency of heart, ears and eyes. However, chapter 30 looks ahead to that need being met in the circumcision of the heart by Yahweh (30:6). Deuteronomy 30:110 is often read as expressing restoration conditional on Israel's repentance, thus placing the onus on Israel. Yet this passage is constructed palistrophically, centred on verse 6 . It is the circumcision of heart which will lead to Israel's repentance, not vice versa. The conditional clauses are temporal, reflecting the consequence of Yahweh's action. This is seen in the syntax of verses 6-8 and the links between verses 2, 8 and 10. Further, 30:1 also acknowledges that Yahweh's words are the prompt for Israel's turning. The Abrahamic promises are the basis for the circumcision of the heart, as is suggested by allusions to the fathers $(30: 5,9)$, the notion of circumcision itself, the promise of land and of increase, as well as the context of the reference to circumcision in 10:15-16.

One of the strongest statements of Israel's ability in Deuteronomy is 30:11-14. These verses are frequently regarded as being in tension with 30:1-10 and deriving from a different redactional layer. However, these verses are also a consequence of 30:6: that is, they are not a statement of present ability. This thesis argues that the present tense of verses $11-14$ is overemphasised by many scholars and commentators. Deuteronomy 30:11-14 forms an outer frame for 30:1-10 with 29:28. The references to the heart in verses $1,2,6,10$, and 14 are chiastic. The '-clause at the beginning of verse 11 is part of the series of such clauses in verses 9-11, also indicating that verses 11-14 are consequential of verse 6 .

The final paragraph of the chapter, Deuteronomy 30:1520 , must be read in the light of 30:1-14. Israel is, in effect, being asked to choose to trust in Yahweh's grace and not in her own ability. The promise of a circumcised heart remains for the 
future, and Israel is to await the fulfilment of that promise in faith. Yet the call for Israel to choose in these verses is not accompanied by any response from Israel. Deuteronomy remains silent. It urges the reader to keep reading beyond itself to see what response is made. Nonetheless, Deuteronomy is pessimistic about the future, as is evident in several ways: the failure of Israel in the past, the identification of the present generation with its predecessor, and the fact that the supply of the heart, eyes and ears which Israel lacks remains as a future promise. Yet Israel's faithlessness does not annul Yahweh's faithfulness. Therein alone lies Israel's hope.

This thesis was restricted in its scope to eight chapters of Deuteronomy. The final chapters of Deuteronomy (Dt. 31-34) support even more obviously the thesis concerning Israel's inability. Though the chapters discussed suggest a filter for reading the legal corpus of Deuteronomy 12-26, a detailed analysis of the theological perspective of the law itself is still required. 